\title{
INFLUENCE OF REQUIREMENTS IN AUTOMOTIVE ROADS AND THEIR STATUS ON THE ESTIMATION OF PROPERTTY VALUATION CHARACTERISTICS
}

\section{ВПЛИВ ПОТРЕБИ В АВТОМОБІЛЬНИХ ДОРОГАХ ТА ЇХ СТАНУ НА ОЦІНКУ МАЙНОВИХ ХАРАКТЕРИСТИК}

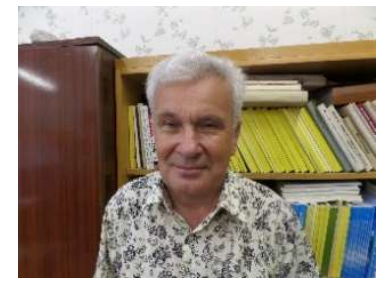

\author{
Lykhostup M., PhD, Candidate of Technical Sciences, Associate \\ Professor, Associate Professor, Department of Transportation \\ Construction and Property Management, National Transport University
}

https://orcid.org/0000-0001-8139-1768

Abstract. Features of the structure of the road economy, as part of the country's economy, affect the creation of a systematic methodology for assessing its property, when individual components will determine the peculiarities of the use and development of road infrastructure. To this end, for the purpose of assessing the property status of highways, which are the main component of the road economy, it is recommended to develop different models of approach to the definition of property valuation of highways.

In the article the directions and models of estimation of the property condition of highways are offered, with the use of different concepts of determining their needs in the infrastructure of the region's economy and the need to maintain them in the proper operating condition. The combination of needs and the state of highways is used as a conceptual criterion for the formation of models for their evaluation as property in the structure of the region's economy. According to this criterion, a road is considered as an object which:

$\boldsymbol{A}$ - provides social and administrative needs for the organization of motor transport in the region and the implementation of passenger transportation;

$\boldsymbol{B}$ - can make a profit as a result of its use;

$\boldsymbol{C}$ - is a part of the main productive assets of the region and the state as a whole, which should be maintained in good condition;

$\boldsymbol{D}$ - a national economic object of a specific purpose, which is used to provide activities of individual sectors of the economy.

The proposed structural classification of highways according to the conceptual criterion of their needs and conditions - $\boldsymbol{A}, \boldsymbol{B}, \boldsymbol{C}$ and $\boldsymbol{D}$ - is the basis for the formation of different models for assessing their property status, the peculiarities of which are discussed in the article. The main principle of such a classification of motor roads and transport facilities in general for the purpose of their property assessment is that they are considered as objects or sub-entities in the models of calculating the property of owners or users of transport facilities.

Keywords: need for roads, road condition, conceptual criterion, model of estimation, property.

\section{Presenting main material}

The property of the road economy is formed by a complex infrastructure of elements for different purposes, for example, roads - objects of operational nature, production enterprises (factories) - elements of the system for ensuring the implementation of labor processes products, machines and mechanisms - these are steel parts of the main production assets of enterprises, and so on. Therefore, the creation of a single methodology for assessing the state of the property of the road economy appears not only as a complex, but also laborconsuming task. Obviously, there is a need to create a systematic methodology for assessing the property of a road economy, the individual structural elements of which (subsystems) will reproduce the features and nature of the development of a particular component of the road economy. 


\section{ЕКОНОМІКА; ОБЛІК І ОПОДАТКУВАННЯ; МЕНЕДЖМЕНТ; МАРКЕТИНГ; ПІДПРИСМНИЦТВО, ТОРГІВЛЯ ТА БІРЖОВА ДІЯЛЬНІСТЬ}

In the process of assessing the property status of the main element of the road economy - roads - should use the conceptual criteria that form the approaches to the goal of such an assessment. In this case, the motorway is considered as an object that provides certain needs (criteria), that is, an automobile road is regarded as an object which:

A - provides social and administrative needs for the organization of motor transport in the region and the implementation of passenger transportation;

B - can make a profit as a result of its use;

$\mathrm{B}$ - is part of the main productive assets of the region and the state as a whole, which should be maintained in good condition for the purpose of widespread use in the national economy and the provision of vital activity in the region;

$\mathrm{G}$ - is a national economic object of a certain purpose, which is used to provide activity of individual branches of the national economy.

The directions of the use of highways are given and form different models of property status assessment, since the criteria and limitations used in determining the needs, the assessment of the state and volume of road maintenance of roads in accordance with the directions of the status of roads (A, B, B and D) should be taken into account in these models. In terms of system analysis are the relationship between these models: model B is focused on obtaining resources for maintenance in a proper condition of the property - roads and transport structures on them, model $\mathrm{C}$ evaluates the state of this property, model $\mathrm{D}$ - determines the directions of improvement of the state of roads for account of the implementation of complexes of construction works and repair and restoration measures, model A - focused on the definition and assessment of the needs of property (roads), taking into account current and future conditions development of a particular region.

The development of the model A of the property state of roads is formed under conditions determined in the process of solving certain engineering and economic problems, such as the task of forming rational routes (transport corridors) or reproduced in models of the region's development. Thus, models for the formation of rational routes (or rational networks of roads or the model for determining short distances of vehicles) have one characteristic feature - it is obtaining data on the expediency of operating an existing or the need to design a new road that would meet the purpose of the problem - set of shortest routes, a minimum the cost of transportation of goods and passengers.

The ideas of the rational development of the networks of roads in the structure of the national economy of the country or the administrative district have always been the subject of theoretical research and practical direction of the activity of individual scientists of the road industry, as well as of entire scientific groups of the relevant branch services, educational establishments and research institutes. In scientific developments and in the practical results that have been achieved in this respect, it is possible to identify several areas in the development of road networks.

The first direction of the development of the network of roads is marked by its physical modeling, when each component of the road is considered as an engineering structure that combines settlements in the structure of the overall system of transport links in the region. In essence, such models use fairly simple optimization approaches aimed at minimizing construction and repairs and reducing losses, both from traffic flows and from negative impacts on the external environment. The most characteristic development of such a principle of modeling the development of the network of roads comes from 1955 to 1985, for example [1,2], which is a characteristic feature of the time of economic development of countries. One of the groups of such models involves the creation in general terms of an "economic and mathematical model of optimization of an integrated transport network", which combines the ideas of the development of all types of transport, and the role of connecting elements of communication is assigned to highways. The rational length of the network of roads of the region in the enlarged form is determined by a simple equation, which uses such parameters as population size, area of the territory, gross volume of agricultural products.

But such simple approximation approaches to the development of the transport network were very simple to determine a truly well-founded network of roads. Therefore, the creation of optimization models for 
determining the rational configuration of the network of highways was more viable and practically feasible. In these models, considerable attention is paid to the study of the minimum value of road transport costs with careful study of the processes of formation of relations between the main parameters that influence the development of the network of roads, as the length of the route between the correspondent points $\boldsymbol{i}$ and $\boldsymbol{j}$, the volume of freight between points $\boldsymbol{i}$ and $\boldsymbol{j}$, road expenses, which ensure the transportation of goods at the site $\boldsymbol{i} \boldsymbol{j}$, transport costs in the same direction, the average speed of transport of vehicles.

The development of mathematical optimization models uses a number of complementary approaches, which, for example, include the use of a system for determining the best transport connection in the regional network, determining the impact of transport on the environment. In turn, solving such auxiliary tasks in global optimization models caused the conduct of such studies, such as, for example, the definition of the system of additional connections in the transport network, the definition of rational adjacency of congresses on main roads, etc.

The second direction is based on the theory of development of variants of work on the network of roads in order to improve both the structure of the network itself and the quality of its transport status, based on the use of models of rational use of capital investments in order to improve their technical level. At the same time, as the main indicator, which determines the best option for the implementation of work, the value of total deductible costs and the profit growth rate, the use of which uses information about the work of transport and the dynamics of work on the merely roads. In recent studies, the use of reduced costs has been expanded to a large number of parameters that are taken into account in models for assessing variants of the development of the network of roads, including the costs of developing competitive types of transport - railways, water transport.

The third direction of the development of the network of roads is based on the use of economic and then socio-economic models. In most of these models, the road is regarded as an element of the general transport system whose task is to organize the reliable transportation of goods and passengers by road. On the other hand, the road is considered as an element of the infrastructure of economic relations between the main functional types of activities that can be developed in the region and satisfies all social needs of the population, including individual residents.

The best example of such models is the implementation of special projects by a consulting firm with a road profile (PM-Consult - Germany, GeoConsult - Austria), which consists in identifying long-term programs of road works in the system of development of the national economy of the region. In general, the idea of a better combination of economic, social and technological and resource opportunities in the development of regional road networks is constantly improving and continues to be used at the level of organization of the work of administrative structures, as evidenced by the activities of the special 15th section of the World Road Congress - PIARC.

The formation of models of the development of the network of roads on the basis of ensuring all the requirements of individual residents for transport connections throughout the year, as a rule, is aimed at developing a local network of roads. In this case, options for the potential development of individual families that can use the appropriate network of roads on the train of their lives are considered. In such models literally there is a simulation of the behavior of individual family members, their labor activities, the development of their own interests, implemented with the use of transport services. The above directions of the formation of the need for highways in certain regions of the country can be taken into account when creating models for assessing their property according to different criteria.

In models of type B the road is considered as the object of obtaining profit from its use. The most widespread forms of development of such models are the development of so-called concession programs and the formation of programs of payment for travel on the roads of a certain destination and certain groups of vehicles. The second direction is considered as more realistic as it is dynamically developing in many countries of the world. 


\section{ЕКОНОМІКА; ОБЛІК І ОПОДАТКУВАННЯ; МЕНЕДЖМЕНТ; МАРКЕТИНГ; ПІДПРИСМНИЦТВО, ТОРГІВЛЯ ТА БІРЖОВА ДІЯЛЬНІСТЬ}

So in 2011-2012, Kapsch Traffic COM AG, in support of the European Integration Program of Ukraine in the Trans-European Transport Network, carried out work on the creation of an electronic payment project for transporting certain groups of transport vehicles by motor roads of specified categories. During the company's cooperation with the employees of Ukravtodor, a concept for the implementation of the electronic payment for travel through 2014 was created. Thus, projects have been created to determine the technical equipment of this system, defined fees for the payment of the train, conditions and plan for organizing work on collection of funds, forms of control and accounting of the work of the system, and so on. But this project has not been realized and is at a stage of possible development.

Conceptual position of the model of payment for transportation of vehicles consists in the formation and solving of such an equation:

$$
\Pi=(N i j x F i x T j)-(B T+P V),
$$

where $\Pi$ - the desired profit from the work of the electronic payment system for road transport, UAH / year;

$i$ - number of groups of vehicles, $i=1,2, \ldots, n$;

$j$ - number of types of payment terminals for fare, $j=1,2, \ldots, m$.

$B T$ - primary expenses for the project realization (creation of terminals of account, control service and account of expenses, expenses for technical devices of cars, expenses for installation and maintenance of cash registers and other measures of technical and organizational nature), UAH;

$P V$ - current expenses for servicing the electronic system of organization and automatic accounting for payment for road transport (maintenance of software, expenses for communication services, current repair and restoration work of equipment) and other costs, which are determined by the method of expert analysis of the work of such systems, UAH;

$N i j$ - is the intensity of traffic of vehicles of the type whose fare on the road should be paid to the j-terminal;

$F i$ - fare for car and other types of vehicles;

$T j$ - is the number of $j$ - th type terminals.

Of course, model (1) is presented in a generalized form, since it lacks the time factor, the coefficient of traffic growth, the parameter of inflation and other parameters that can develop the model. But in this model there is essentially one parameter that regulates and evaluates the efficiency of this model - this is the value of the fare - and this parameter is determined in the process of solving the model (1) at the given value of $\Pi$. In turn, the value of $\Pi$ (the meaning of the implementation of the system fare) can be set in the range of $15-20 \%$ of the total value $(\mathrm{BT}+\mathrm{PV})$.

In type $\mathrm{C}$ models, the road and its associated transport facilities are considered as part of the main productive assets of the region and the state as a whole. The state of highways and their transport facilities determines the volume of certain road construction works and repair and restoration measures, the totality of which determines the general needs for financial resources and determines the residual value of the object. Determination of the residual value of the objects of the road economy is formed on the basis of the following principles:

- each and every element of the road $(i=1,2, \ldots, \mathrm{n})$ or $\mathrm{s}$ - and the transport structure $(s=1,2, \ldots, S)$ has its initial cost, which was fixed at the cost of execution works on its creation or was determined by the rules of the market price - respectively Voi or Vos;

- each element of the road or its related transport facilities has certain service life, that is, the terms of validity in terms of their suitability for use - respectively, Toi or Tos. These terms of service are best defined using the advanced expert appraisal method, since the use of so-called degradation models for most elements and transport constructions is seen as a virtually impossible approach. The research carried out in this way on previous stages of the implementation of the scientific works [3] made it possible to compile tables of terms of service of elements of roads and transport constructions. - at the time of evaluation of property - the residual value of an element of roads and structures - each element is on a certain period of service ( $\boldsymbol{a}$ : this term has not yet come, $\boldsymbol{b}$ : just ended, $\boldsymbol{c}$ : already passed); 
- for each item and transport structure that are components of a particular object, the possibilities of road construction works or repair and restoration measures performed to improve their condition are considered and fixed costs of their implementation. Possible fixing of different options for carrying out works and repairs - 1: were carried out in different situations of fixing the service life of elements of roads or transport facilities - $\boldsymbol{a}: \boldsymbol{b}: \boldsymbol{c} ; 2$ - work and measures were not implemented- using existing methods of estimating the residual value of the main production facilities of the road economy, the residual values of each element or transport structure are calculated - respectively Zoi or Zos;

- the total residual value of the object as part of the property of the road economy is defined as the sum of the residual value of each element or transport facility - Zoi or Zoi.

Obtained values of the total residual value of the object (part of the property) are used to solve various practical tasks related to the formation of the resource supply system of the object necessary for its maintenance in the proper operating condition, the formation of the accounting and reporting system and other tasks .

Models of type $\boldsymbol{D}$ are focused on the decision of tasks of planning of resource provision of property objects in order to provide activity of certain branches of the national economy. Models of resource planning for maintenance processes in the normal operating status of distributed objects in Europe should include the model HDM-IV, various models of the PMS type and the Ukrainian model of the SUSP (СУCП), the basis of which was developed in 1996-2001 [4], and the reproduction of this model takes place during the year 2017 for Ukravtodor.

In the latest version of the SUSP model, as in its previous versions, the planning of resource provision of road objects is carried out through a repair system - capital and medium - as well as certain current maintenance repairs. In the latest version of the SUSP model, seven repair strategies are considered, namely:

Strategy 1, which defines the so-called standard terms for repairs of non-rigid type of road surface, consists of two middle repairs between adjacent major repairs, the basis of which is determining the development of the value of the modulus of elasticity of road clothing and forecasting the volume of annual destruction of the travel section.

Strategy 2, which is aimed at fulfilling the condition of non-exodus of road wear outside the permissible (project in accordance with category and traffic flow). Thus, the criterion of the formation of repair strategies in this case is the equality of coverage. According to this strategy, two middle repairs are carried out, and the terms of their carrying out, as well as the power of repairs are calculated autonomously, that is, independently of each other. But the equality of coverage should have the same acceptable value in these two cases.

Strategy 3, which is also focused on the implementation of the condition of non-exodus of road wear beyond the permissible, but with the condition of three average repairs in period $0-\mathrm{T}$. Strategy 4 defines the conditions for carrying out two stages of capital repairs and a series of average repairs in the same period $0-\mathrm{T}$, provided that the regulatory equality of coverage is observed. Strategy 5, which determines the conditions for major repairs in the period $\mathrm{Tk}<=6$ years and which develops in two directions:

Strategy 5a: Defined by the fact that at first one average repair is carried out before major repairs are carried out. Then, two average repairs are made on conditions of non-exodus of road clothes beyond the permissible value of strength. If the definition of such a strategy for the implementation of road repair measures is targeting the permissible equality of road coverage.

Strategy 5 b: Determined by the fact that at first one average repair is carried out before major repairs are carried out in the event of non-exit of the transport condition of road wear (strength) under admissible conditions, then one major repair is carried out, and then, at regular intervals, two average repairs are made with the cost respectively.

Strategy 6 , considering the possibility of major repairs in the period Tk> 6 years. The development of such a strategy includes the following steps: first, 2 average repairs are carried out during the period of overhaul, that is, in the period $0-\mathrm{Tk}$, in the estimated year Tk, the capital repairs are carried out by value, and then one more average repair after the Tk period is performed. 
Strategy 7, which deals with mathematical models of the justification of two stages of capital repairs without carrying out mid-repairs of average repairs.

The main requirement for determining the terms and capacity of major repairs is the desired equality of coverage, and the implementation of major repairs is accompanied by work on the current minor repairs and maintenance of the road as a whole. In the process of planning average repairs, as the main limitation, the equality of coverage and the coefficient of adhesion of the coating to the surface of the road is taken as the main limitation. The criteria for choosing a better strategy for carrying out road repair work are the values of road and transport costs, and the choice of the best value of this criterion is determined in the process of interactive dialogue.

The above directions for determining needs, assessing the state and establishing resource support for maintenance in a reliable operational condition of highways should be used in the development of a system of models for their property valuation. Such models of property status assessment can be developed as stand alone for further practical use, and used in the light of information that will be obtained from other models. In any case, the complexity of the solution to the problem of property valuation of motor roads is evident and comprehensively reflects the dynamics of requirements for the movement of property - the quantity and quality of transport and operational condition of highways.

\section{Conclusions}

Features of the structure of the road economy determine the various approaches to valuing the property of its constituent elements. In order to assess the property of roads as the main component of the road economy, various approaches and techniques may be developed where a road is considered as part of the regional economy's infrastructure as an object of income or as the state's main assets requiring its maintenance of resources. But the prospect of developing such stand-alone approaches to property valuation requires the creation of a comprehensive strategic model for the property valuation of individual roads and network of roads of a certain destination.

\section{References}

1. Khomyak Ja. V. Proektirovanie setey avtomobilnych dorog. - M.: Transport. - $1983-183$ c.

2. Braun J. Adaptive Ermittlung kuerzester Route in Verkehrswegenetzen. / Schriftreihe des Instituts für Verkehrsplanung und Verkehrswesen der Technischen Universität Muenchen // - H.15, 1980. - S. 151.

3. Likhostup M.M. Dovgostrokove planuvannja dorojnogo gospodarstva za ozinkamy dorojnich aktuviv //Avtomobilni dorogj i doroschne budivnuztvo. - Vyp. 94. - K: Vyd -vo NTU, 2015. -c. 135 - 149.

4. Kyzyma S. S. Rozvytok systemy dovgostrokovogo planuvannja dorojnogo gospodarstva. /Kyzyma S.S., Likhostup M.M. // Avtomobilni dorogj i doroschne budivnuztvo. - Vyp. 97 - K.: Vyd - vo NTU, - 2016. - c. $103-113$.

5. Kyzyma S., S. Rekomendazii po vykorystannu SUSP dlja planuvannja remontnych robit./ Kyzyma S., S., Kanin O.P., Lichostup M.M. //Derschavna sluschba avtomobilnych dorig Ukrainy (Ukravtodor). - K.: $-2002.18 \mathrm{~s}$.

6. Kanin O.P. Informaziyno-analitychna systema upravlinnja dovgostrokovymy kontraktamy na osnovi rivniv obslugovuvannja dorig. /Avtomobilny dorogy i doroschne budivnyztvo. Vyp.94 - K.: Vyd-vo HTU, 2015. - C.112 - 123.

7. Mazur I.I. Upravlenie proektami. /Mazur I.I., SCHapiro V.D. i dr. Spravochnoe posobie.// - M.: Vysshaja shkola. - $2001-875$ s.

8. Bronstein L.A. Ekonomika doroshnogo stroitelstva. /pod. red. Bronsteina L.A..// - M.: Transport. $1971-304 \mathrm{~s}$.

\section{ВПЛИВ ПОТРЕБИ В АВТОМОБІЛЬНИХ ДОРОГАХ ТА ЇХ СТАНУ НА ОЦІНКУ МАЙНОВИХ ХАРАКТЕРИСТИК}

Лихоступ Микола Миколайович, кандидат технічних наук, доцент, доцент кафедри транспортного будівництва та управління майном Національного транспортного університету, https://orcid.org/0000-0001-8139-1768 
Анотація. Особливості структури дорожнього господарства, як складової частини економіки країни, впливають на створення системної методики оцінки його майна, коли окремі складові будуть визначати особливості використання та розвитку дорожньої інфраструктури. 3 цією метою для оцінки майнового стану автомобільних доріг, які є основною складовою частиною дорожнього господарства, рекомендується розробка різних моделей підходу до визначення майнової оцінки автомобільних доріг.

В статті запропоновані напрямки та моделі оцінки майнового стану автомобільних доріг при умові використання різних концепцій визначення іх потреби в інфраструктурі економіки регіону та необхідності у підтримання їх в належному експлуатаційному стані. Сполучення потреби та стану автомобільних доріг використовується як концептуальний критерій по формування моделей їх оцінки як майна в структурі економіки регіону. За таким критерієм автомобільна дорога розглядається як об'єкт, який:

$\boldsymbol{A}$ - забезпечує соціально - адміністративні потреби в організації руху автомобільного транспорту в регіоні та здійсненні пасажирських перевезень;

$\boldsymbol{B}$ - може принести прибуток в результаті свого використання;

$\boldsymbol{C}$ - являється частиною основних виробничих фондів регіону та держави в цілому. які повинні бути підтримані в належному стані;

$\boldsymbol{D}$ - народно-господарчий об'єкт певного цільового призначення, який використовується для забезпечення діяльності окремих галузей народного господарства.

Запропонована структурна класифікація автомобільних доріг за концептуальним критерієм їх потреби та стану $-\boldsymbol{A}, \boldsymbol{B}, \boldsymbol{C}$ та $\boldsymbol{D}$ - є основою для формування різних моделей оцінки їх майнового стану, особливості розвитку яких і розглядаються в статті. Головним принципом такої класифікації автомобільних доріг та транспортних споруд в цілому з метою їх майнової оцінки $є$ те, що вони розглядаються як об'єкти або суб”єкти в моделях розрахунку майна власників чи користувачів транспортних споруд.

Ключові слова: потреба в дорогах, стан дороги, концептуальний критерій, моделі оцінки, майно.

\section{Перелік посилань}

1. Хомяк Я. В. Проектирование сетей автомобильных дорог. - М.: Транспорт. - 1983 - 183 с.

2. Braun J. Adaptive Ermittlung kuerzester Route in Verkehrswegenetzen. / Schriftreihe des Instituts für Verkehrsplanung und Verkehrswesen der Technischen Universität Muenchen // - H.15, 1980. - S. 151.

3. Лихоступ М.М. Довгострокове планування дорожнього господарства за оцінками дорожніх активів /Автомобільні дороги і дорожне будівництво. - Вип. 94. - К: Вид -во НТУ, 2015. -c. 135 - 149.

4. Кизима С. С. Розвиток системи довгострокового планування дорожнього господарства.Кизима С.С., Лихоступ М.М. // Автомобільні дороги і дорожнє будівництво.. - Вип. 97 - К.: Вид - во НТУ. - 2016. - c. 103 - 113.

5. Кизима С.С. Рекомендації по використанню СУСП для планування ремонтних робіт./ Кизима С.С., Канін О.П., Лихоступ М.М.// Державна служба автомобільних доріг України (Укравтодор). - К.: $-2002.18 \mathrm{c}$.

6. Канін О.П. Інформаційно - аналітична система управління довгостроковими контрактами на основі рівнів обслуговування доріг //Автомобільні дороги і дорожнє будівництво. Вип.94 - К.:

Вид-во НТУ, 2015. - С.112 - 123.

7. Мазур И.И. Управление проектами. /Мазур И.И., Шапиро В.Д. и др. Справочное пособие.// М.: Высшая школа. $-2001-875$ с.

8. Бронштейн Л.А. Экономика дорожного сьроительства. /под ред. Бронштейна Л.А.// - М.: Транспорт. $-1971-304$ с. 